ISSN: 2536-5339

\title{
Dynamic Balance Ability and Hypermobility in Pre-School Children Who Participate Gymnastic Training
}

\author{
İnci KESILMiş ${ }^{1}$ \\ Manolya AKIN ${ }^{1}$ \\ ${ }^{1}$ Mersin University, Department of Physical Education and Sports, MERSIN
}

Künye: Kesilmiş, İ ve Akın, M. (2018). Dynamic Balance Ability and Hypermobility in Pre-School Children Who Participate Gymnastic Training. Gaziantep Üniversitesi Spor Bilimleri Dergisi, 3(3): 78-87.

\begin{abstract}
The aim of this study was to examine dynamic balance ability and hypermobility according to gender and gymnastics training participation in 6 years of age children. In this research, 76 male and 86 female totally 162 children with the mean body height $114.51 \pm 5.15 \mathrm{~cm}$ and with the mean body weight $20.54 \pm 3.73 \mathrm{~kg}$ participated voluntarily. While 47 of the children participating gymnastics training for 12 weeks, 115 of the children continued regular pre-school program. Dynamic balance ability measured by prokin tecno body with easy base for 30 seconds. Hypermobility identified by The Beighton criteria and cut-off point was taken as 4. For dynamic balance ability in 6 years of age there were statistically significant difference in favor of gymnastic participation compared with the others $(p<0.001)$. There was a statistically significant difference in dynamic balance ability in favor of girls, according to gender $(p<0.005)$. And hypermobility was significantly different in favor of gymnastic participation $(p<0.05)$. The hypermobility rate of males is $23.7 \%$, females is $43 \%$, gymnasts is $51.1 \%$ and sedentary is $27 \%$. There wasn't any correlation between dynamic balance ability and hypermobility. As a result, although they have similar physical characteristics and in the same age group, their dynamic balance performance and hypermobility differentiated depending on factors of gymnastics training and also it was observed that the dynamic balance performance was in favor of girls. This study emphasized the importance of early participation in gymnastics.
\end{abstract}

\section{Original Article}

Article Info

Received: 16.08 .2018

Accepted: 07.09.2018

Published: 24.09.2018

\section{Corresponding Author}

e-mail: incikesilmis@mersin.edu.tr

DOI: $10.31680 / g a u n j s s .453979$

Keywords: Dynamic balance, hypermobility, preschool, gymnastics. 


\section{Introduction}

Balance or postural control is essential in everyday life. It allows performance of activities that range from maintenance of static positions to complex dynamic activities (Rombaut et al., 2011). Also, balance is an integral part of almost every movement task and at the foundation of athletic performance. Dynamic balance is the ability to perform a task while preserving or regaining a stable position (Winter, Patla and Frank, 1990) or the ability to maintain or regain balance with minimal external motion on an unstable surface (Kioumourtzoglou et al., 1997; Paillard, et al., 2006; Hrysomallis, 2011). The most significant transitions in motor development occur in the first decade of life with balance control (Roncesvalles et al, 2001). Naturally, gymnastic training must be start at early ages to perform perfect skills and so balance is the key factor for complex gymnastic skills. Dynamic balance tests require participants to demonstrate strength, flexibility, proprioception, and concentration coupled with motion and coordination between the ankle, knee, and hip joints, as well as motion at the trunk. Each reach direction requires different activation of the lower extremity muscles (Earl and Hertel, 2001). In some studies mentioned about gender differences on dynamic balance ability. In a study conducted with children in Australia, males showed more postural sway at all static and dynamic equilibrium than females (Mickle et al., 2011). In addition, there are a number of studies that have reached the conclusion that females are more advantageous in balance ability (Mickle et al., 2011; Geldhof et al., 2006). Gymnastics involves balanced movements of the body while at the same time it is one of the sports branches that require flexibility. A wide range of movement at the lumbar spine, hips and shoulders is required in gymnastics.

The required flexibility in gymnastics is sometimes intermingled concept. Joint hypermobility syndrome is a heritable disorder of the connective tissue characterized by excessive joint movement, musculoskeletal pain and neurophysiological deficits (Iatridou et al., 2013; Grahame et al., 2000). A joint is considered hypermobile when it exhibits a range of motion greater than expected for a given age, ethnicity or gender (Hakim and Grahame, 2003; Simmonds and Keer, 2007). Children inherently have a greater range of joint motion than adults, the prevalence of hypermobility, as defined by several criteria, varying in different populations from 5 to $30 \%$ (Qvindesland and Jonsson, 1999). In musicians, athletes and dancers hypermobility is more pronounced, probably because hypermobility is an asset to these professions 
(Klemp et al., 1984). This is thought to be true, because joints that do not participate in the specific training also tend to be more lax than in other populations (Rikken et al., 1997). Many studies have shown that there is wide variation in the prevalence of joint hypermobility. Hypermobility decreases during the ongoing growth process from childhood (Hakim and Grahme, 2003; Jansson et al., 2004; Rikken et al., 1997; Decoster et al., 1997). It can be considered that hypermobility may be an advantage or disadvantage in various branches, which is thought to affect balance ability. And so, it can be a research topic that gymnasts have much in common with ballet and hypermobility would at first sight be deemed an advantage.

There are few studies in the literature between hypermobility and dynamic balance (Akın et al., 2017; Kesilmis et al., 2017; Kesilmis \& Akın, 2016; Falkerslev et al., 2013; latridou et al., 2014). Therefore, the main purpose of this study is to compare dynamic balance ability and hypermobility between children that participate gymnastics training and sedentary in 6 years of age and also to find out the gender differences.

\section{Materials and Methods}

\section{Participants}

Seventy-six male and 86 female totally 162 children with the mean body height $114.51 \pm 5.15 \mathrm{~cm}$ and with the mean body weight $20.54 \pm 3.73 \mathrm{~kg}$ participated voluntarily. While 47 of the children participating gymnastics training for 12 weeks, 115 of the children continued regular school program. Informed consent form procedure as required by the Helsinki declaration (2008) signed by the entire participant, their parents and the trainer prior to the study.

\section{Dynamic Balance}

Dynamic balance ability was measured with Prokin Tecno Body (PK200WL, Italy). Easy type was used to measure bipedal dynamic balance ability for 30 seconds. Once the investigator was made the necessary preliminary information about the measurement, then two trials were done by children to become familiar for the test. After providing the position of the balance with bare feet and thin sportswear, test was started. The measurement repeated if participant fall over before the end of the test. Each child participated balance measurement for two times and the rest period between test was 60 second. 


\section{Hypermobility}

The Beighton test is the best commonly used tool for detecting ligamentous hiperlaxity, characterized by excessive joint mobility (Ortega et al., 2010). Hypermobility was measured by Beighton criteria (Beighton, 1973). These are as follows; Passive dorsiflexion of the little fingers beyond $90^{\circ}$ (one point for each hand) - two points. Passive apposition of the thumbs to the flexor aspects of the forearm (one point for each thumb) - two points. Hyperextension of the elbows beyond $10^{\circ}$ (one point for each elbow) - two points. Hyperextension of the knee beyond $10^{\circ}$ (one point for each knee) - two points. Forward flexion of the trunk with knees fully extended so that the palms of the hands rest flat on the floor - one point. Each hypermobile joint gives 1 point and so the maximum score being 9 points. With four or more points assigned, the individual is considered to be hypermobile (Birrel et al., 1994; Hudson et al., 1995).

\section{Statistics}

Normality test has been applied and identified that data has statistically normal distribution. Then for statistical analyses independent samples $t$ test used to compare gymnasts and sedentary and to compare males and females. Also, partial eta squared was calculated as measures of effect size.

\section{Results}

Table 1: Mean, Standard Deviation and independent samples t tests according to participating gymnastics training

\begin{tabular}{|c|c|c|c|c|c|c|c|c|}
\hline & & $\mathbf{N}$ & Mean & SD & $t$ & Sig & Cohens'd & Effect Size $r$ \\
\hline \multirow{2}{*}{$\begin{array}{l}\text { BODY HEIGHT } \\
(\mathrm{cm})\end{array}$} & Sedentary & 115 & 114,20 & 5,15 & $-1,198$ & .23 & -0.207 & -0.103 \\
\hline & Gymnasts & 47 & 115,27 & 5,14 & & & & \\
\hline \multirow{2}{*}{$\begin{array}{l}\text { BODY WEIGHT } \\
(\mathrm{kg})\end{array}$} & Sedentary & 115 & 20,31 & 4,04 & $-1,26$ & .20 & -0.234 & -0.116 \\
\hline & Gymnasts & 47 & 21,12 & 2,76 & & & & \\
\hline \multirow{2}{*}{ BEIGHTON } & Sedentary & 115 & ,296 &, 44 & $-3,004$ & $.003^{*}$ & -0.454 & -0.221 \\
\hline & Gymnasts & 47 &, 510 &, 50 & & & & \\
\hline \multirow{2}{*}{$\begin{array}{l}\text { PERIMETER } \\
\text { LENGTH }\end{array}$} & Sedentary & 115 & 608,55 & 184,78 & 5,841 & .000 ** & $1.068^{\phi}$ & 0.471 \\
\hline & Gymnasts & 47 & 433,61 & 139,61 & & & & \\
\hline \multirow{2}{*}{$\begin{array}{l}\text { AREA GAP } \\
\text { PERCENTAGE }\end{array}$} & Sedentary & 115 & 29,01 & 15,70 & 4,112 & $.000 * \star$ & $0.721^{\phi}$ & 0.339 \\
\hline & Gymnasts & 47 & 18 & 14,82 & & & & \\
\hline \multirow{2}{*}{ MEDIUM SPEED } & Sedentary & 115 & 20,34 & 6,15 & 6,701 & $.000 * *$ & $1.260^{\phi}$ & 0.533 \\
\hline & Gymnasts & 47 & 13,84 & 3,92 & & & & \\
\hline \multirow{2}{*}{ MECAP } & Sedentary & 115 &, 04 & 3,55 & 0,492 & .62 & 0.094 & 0.047 \\
\hline & Gymnasts & 47 &,- 21 & 1,19 & & & & \\
\hline \multirow{2}{*}{ MECML } & Sedentary & 115 & $-1,59$ & 3,89 & $-1,826$ & .07 & -0.364 & -0.179 \\
\hline & Gymnasts & 47 &,- 52 & 1,45 & & & & \\
\hline
\end{tabular}


As shown in Table 1, beighton scores were significantly different in favor of gymnastic group. Also, for dynamic balance ability, Perimeter Length, Area gap percentage and medium speed values are significantly different in favor of gymnastic group.

Table 2: Mean, Standard Deviation and independent samples tests according to gender

\begin{tabular}{|c|c|c|c|c|c|c|c|c|}
\hline & Gender & $\mathbf{N}$ & Mean & SD & $\mathbf{t}$ & Sig & Cohens'd & Effect Size $r$ \\
\hline \multirow{2}{*}{ BEIGHTON } & Male & 76 & ,236 & ,427 & $-2,633$ & $.009 *$ & -0.418 & -0.204 \\
\hline & Female & 86 & ,430 & ,498 & & & & \\
\hline \multirow{2}{*}{ PL } & Male & 76 & 607,77 & 189,91 & 3,239 & $.001^{*}$ & $0.509^{\phi}$ & 0.246 \\
\hline & Female & 86 & 513,63 & 179,78 & & & & \\
\hline \multirow{2}{*}{ AGP } & Male & 76 & 29,09 & 15,19 & 2,458 & $.01^{*}$ & $0.387^{\phi}$ & 0.190 \\
\hline & Female & 86 & 22,92 & 16,59 & & & & \\
\hline \multirow{2}{*}{ MS } & Male & 76 & 20,10 & 6,37 & 3,205 & $.002^{\star}$ & $0.503^{\phi}$ & 0.244 \\
\hline & Female & 86 & 17,00 & 5,93 & & & & \\
\hline \multirow{2}{*}{ MECAP } & Male & 76 &,- 13 & 2,77 & $-0,397$ & .69 & -0.059 & -0.029 \\
\hline & Female & 86 & ,05 & 3,30 & & & & \\
\hline \multirow{2}{*}{ MECML } & Male & 76 & $-1,22$ & 3,32 & 0,204 & .83 & 0.032 & 0.016 \\
\hline & Female & 86 & $-1,33$ & 3,49 & & & & \\
\hline
\end{tabular}

${ }^{{ }^{*}} p<.05^{\star} p<.05$, Effect size, Cohen's $d .{ }^{\phi} p<.001$

Table 3: Hypermobilite ratios of males, females, gymnasts and sedentary

\begin{tabular}{llcc}
\hline \multirow{2}{*}{ Male } & & Frequency & Percent \\
\cline { 2 - 4 } & Nonhypermobile & 58 & $76,3 \%$ \\
\hline Female & Nonhypermobile & 18 & $23,7 \%$ \\
\cline { 2 - 4 } & Hypermobile & 49 & $57 \%$ \\
\hline Sedentary & Nonhypermobile & 37 & $43 \%$ \\
\cline { 2 - 4 } & Hypermobile & 31 & $73 \%$ \\
\hline Gymnasts & Nonhypermobile & 23 & $48,9 \%$ \\
\cline { 2 - 4 } & Hypermobile & 24 & $51,1 \%$ \\
\hline
\end{tabular}

The results of present study showed a statistically significant difference in beighton scores, perimeter length, area gap percentage, medium speed according to gender. For dynamic balance females showed better performance than males and also ratio of hypermobility in females (43\%) is better than males $(23.7 \%)$. 


\section{Discussion}

The results of this study showed that dynamic balance ability is better in favor of children who participate gymnastics trainings. Gymnastic training group clearly showed better performance for perimeter length, area gap performance and medium speed. The results of the present study strengthened the important role of gymnastics training for dynamic balance ability in 6-year-old children as well. In accordance with our study, Alpkaya 2013 conducted a study with seven-year-old girls and ten weeks gymnastics training program was found beneficial for children and suggested that gymnastics training improved balance parameters. Similarly, in a study that researched the effect of eight weeks gymnastics training on gross motor skills including balance in 5-6 years of age children, reached the result that pre-level gymnastic exercises effects positively balance development (Fallah et al., 2015). Also, Kioumourtzoglou et al. (1997) showed that elite gymnasts have better dynamic and static balance than novices. In a study conducted by Davlin (2004), gymnasts were superior to all others in dynamic balance ability when compared to control group, swimmers and footballers. There are also some studies that find out gymnasts had better performance in dynamic balance ability when compared to control or different sport branches (Aydın et al., 2002; Asseman et al., 2008; Kioumourtzoglou et al., 1997). So; like many other studies, the positive effects of gymnastics training on the dynamic balance are evident in our research. It is clear that by participating in gymnastics training at an early age, positive contributions to dynamic balance ability can be achieved. Because during the preschool years, balance reaches an adequate level, while its development is completed in later childhood (Scheid, 1994).

In literature on balance abilities at the preschool children, females have better scores than males (Alves et al., 2013; Fjørtoft, 2000; Lejarraga et al., 2002; Lam et al., 2003) and on the other hand, several researchers report no significant differences on dynamic balance ability between preschool children according to gender (Davlin, 2004; Kourtessis et al., 2008; Venetsanou, 2007). In recent research dynamic balance ability findings that in favor of females showed on perimeter length, area gap percentage and medium speed.

In addition, we found that the beighton score was significantly different between gymnasts and sedentary in favor of gymnasts. And also, in our study hypermobility was significantly different according to gender in favor of females. In literature, there are some studies that have shown similarity results as our research 
(Ortega et al., 2010; Jansson et al.,, 2004; Yıldırım et al., 2005). Hypermobility diminishes with age from childhood onward, is about three times more common in female than males (Hakim and Grahame, 2003). Our findings suggest that knowledge. The hypermobility rate of males is $23.7 \%$, females is $43 \%$, gymnasts is $51.1 \%$ and sedentary is $27 \%$. Qvindesland and Jonsson (1999) conducted a study with 143 female and 124 male and reported that hypermobility seadrome was $40.5 \%$ in females and $12.9 \%$ in males. In a study by Ortega et al. (2010); there were 2956 children participant \%49.9 male \%50.1 female from eight to twelve years and in accordance with our study females were more hypermobile than males.

\section{Conclusions}

According to our research, it was observed that the group participating in gymnastics training and also females had better dynamic balance and more hypermobile. Positive contributions from participating in sportive activities from childhood are an indisputable fact. Ferrell et. al. (2007) put emphasis on that adequate training improves proprioception as well as balance. Moreover, balance training not only improves balance but also reduces pain and thus has a positive effect on quality of life on the hypermobile person. From these findings, the balance achieved in sportive activities are a necessary motor ability for life. Thus, sportive activities should be encouraged from childhood and regular and continuous participation in sportive activities can contribute to motor development.

\section{References}

Akın, M., Sallayıcı, M., Kesilmiş, İ., Kesilmiş, M. M. (2017). Determining the correlation between dynamic balance ability to plantar flexion and dorsi flexion range of motion in swimmers. Turkish Clinics Journal of Sports Science, 9(2), 71-76.

Alpkaya, U. (2013). The effects of basic gymnastics training integrated with physical education courses on selected motor performance variables. Academic Journals Educational Research and Reviews, 8(7), 317-321.

Alves, R.F., Rossi, A.G., Pranke, G.I., Lemos, L.F.C. (2013). Influence of gender in postural balance of school age children. Rev. CEFAC, 15(3), 528-536.

Asseman, F. B., Caron, O., Cremieux, J. (2008). Are there specific conditions for which expertise in gymnastics could have an effect on postural control and performance? Gait \& Posture, 27, 76-81. 
Aydin, T., Yildiz, Y., Yildiz, C., Atesalp, S., Kalyon, T.A. (2002). Proprioception of the ankle: a comparison between female teenaged gymnasts and controls. Foot Ankle International, 23(2), 123-129.

Beighton, P., Grahame, R., Bird, H. (2012). Hypermobility of Joints. Fourth Edition. Springer.

Beighton, P.H., Solomon, L., Soskolne, C.L. (1973). Articular mobility in an African population. Annals of the Rheumatic Diseases, 32(5), 413-417.

Birrell, F.N., Adebajo, A., Hazleman, B.L., Silman, A.J. (1994). High prevalence of joint laxity in West Africans. British Journal of Rheumatology, 33, 56-9.

Davlin, C.D. (2004). Dynamic balance in high level athletes. Perceptual Motor Skills, 98(3), 1171-1176.

Decoster, L.C., Vailas, J. C., Lindsay, L.H., Williams, R. (1997). Prevalance and features of joint hypermobility among adolescent athletes. Arc Pediatr Adolesc Med, 151(10), 989-992.

Earl, J., Hertel, J. (2001). Lower extremity muscle activation during the Star Excursion Balance Test. Journal of Sports Rehabilitation, 10(2),93-105.

Falkerslev S, Baagø C, Alkjær T, Remvig L, Halkjær-Kristensen J, Larsen PK, JuulKristensen B, Simonsen EB. (2013). Dynamic balance during gait in children and adults with generalized joint hypermobility. Clin Biomech, 28(3), 318-324.

Fallah, E., Nourbakhsh, P., Bakherly, J. (2015). The effect of eight weeks of gymnastics exercises on the development of gross motor skills of five to six years old girls. European Online Journal of Natural and Social Sciences, 4(1), 845-852.

Ferrell, W.R., Tennant, N., Baxendale, R.H., Kusel, M., Sturrock, R.D. (2007). Musculoskeletal reflex function in the joint hypermobiliy syndrome. Arthritis Rheum, 57(7), 1329-1333.

Fjørtoft, I. (2000). Motor fitness in pre-primary school children: the EUROFIT Motor Fitness Test explored on 5-7-year-old children. Pediatric Exercise Science, 12, 424-436.

Geldhof E, Cardon G, De Bourdeaudhuij I, Dannaells, E., Coorevits, P., Vanderstraeten, G., De Clercq, D. (2006). Static and dynamic standing balance: test-retest reliability and reference values in 9 to 10 year old children. Eur J Pediatr, 165(11), 779-786.

Grahame, R., Bird, H.A., Child, A. (2000). The revised (Brighton 1998) criteria for the 
diagnosis of benign joint hypermobility syndrome (BJHS). Journal of Rheumatology, 27(7), 1771-1779.

Hakim, A., Grahame, R. (2003). Joint hypermobility. Best Pract Res Clin Rheumatol, 17, 989-1004.

Hrysomallis, C. (2011). Balance abilities and athletic performances. Sports Medicine, 41, 221-232.

Hudson, N., Starr, M.R., Esdaile, J.M., Fitzcharles, M.A. (1995). Diagnostic associations with hypermobility in rheumatology patients. $\mathrm{Br} \mathrm{J}$ Rheumatol, 34, 1157-1161.

latridou, G., Dionyssiotis, Y. (2013). Reliability of balance evaluation in children with cerebral palsy. Hippokrattia, 17(4), 303-306.

Jansson, A., Saartok, T., Werner, S., Renström, P. (2004). General joint laxity in 1845 Swedish school children of different ages:age and gender specific distributions. Acta Pediatr, 93, 1202-1206.

Kesilmiş, İ., Akın, M. (2016) 4-6 yaş çocuklarda cimnastik antrenmanının biyomotor yetiler üzerine etkisi. Türkiye Klinikleri Spor Bilimleri Dergisi, 8(1), 15-21. DOI: 10.5336/sportsci.2015-47651.

Kesilmiş, I., Kesilmiş, M.M., Akın, M. (2017). The correlation between ankle range of motion and dynamic balance ability in rhythmic gymnasts. International Journal of Physiotherapy and Research, 5, 2265-2270.

Kioumourtzoglou, E., Derri, V., Mertzanidou, O., Tzetzis, G. (1997). Experience with perceptual and motor skills in rhythmic gymnastics. Perceptual and motor skills, 84(3), 1363-1372.

Klemp, P., Stevens, J.E., Isaacs, S. (1984). A hypermobility study in ballet dancers. Journal of Rheumatology, 11, 692-696.

Kourtessis, T., Tsougou, E., Maheridou, M., Tsigilis, N., Psalti, M., \& Kioumourtzoglou, E. (2008). Developmental coordination disorder in early childhood - A preliminary epidemiological study in Greek schools. The International Journal of Medicine, 1(2), 95-99.

Lam, M.Y., Ip, M.H., Lui, P.K. \& Koong, M.K. (2003). How teachers can assess kindergarten children's motor performance in Hong Kong. Early Child Development and Care, 173, 1, 109-118.

Lejarraga, H., Pascucci M. C. , Krupitzky, S., Kelmansky D., Bianco, A., Martinez E., Tibaldi, F. \& Cameron, N. (2002). Psychomotor development in Argentina 
children aged 0-5 years. Paediatric and Perinatal Epidemiology, 16, 47-60.

Mickle KJ, Munro BJ, Steele JR. (2011). Gender and age affect balance performance in primary school-aged children. J Sci Med Sport, 14(3), 243-248.

Ortega, F.Z., Rodrigues, L.R., Martinez, A.M., Sanchez, M.F., Paiz, C.R., Liria, R.L. (2010). Hiperlaxity ligamentou (Beighton test) in the 8 to 12 years of age school population in the province of Granada. Reumatol Clin, 6(1), 5-10.

Qvindesland, A., Jonsson, H. (1999). Articular hypermobility in Icelandic 12-yearolds. Rheumatology, 38, 1014-1016.

Paillard, T., Noe, F., Riviere, T., Marion, V., Montoya, R., Dupui, P. (2006). Postural performance and strategy in the unipedal stance of soccer players at different levels of competition. Journal of Athletic Training, 41(2), 172-176.

Rikken-Bultman, D.G.A., Wellink, L., Van dongen P.W.C. (1997). Hypermobility in two Dutch school populations.European Journal of Obstetrics \& Gynecology and Reproductive Biology, 73(2), 189-192.

Rombaut, L., Malfait, F., De Wandele, I., Thijs, Y., Palmans, T., De Paepe A, Calders, P. (2011). Balance, gait, falls, and fear of falling in women with the hypermobility type of Ehlers-Danlos syndrome. Arthritis Care Res (Hoboken), 63(10), 1432-1439.

Roncesvalles, M.N.C., Woollacott, M.H., Jensen, J.L. (2001). Development of lower extremity kinetics for balance control in infants and young children. J Mot Behav, 33(2), 180.

Scheid, V. (1994). Motorische entwicklung in der frühen kindheit. in: k. baur, k. boes, r. singer (ed.) motorische entwicklung. ein handbuch. Schorndorf: Hofmann. 260-275.

Simmonds, J.V, Keer, R.J. (2007). Hypermobility and the hypermobility syndrome. Man Ther, 12, 298-309.

Venetsanou, F. (2007). A study on the motor development of preschool aged children in Peloponnesus territory. Doctoral Thesis. Department of Physical Education and Sport Sciences, Democritus University, Greece.

Winter, D.A., Patla, A.E., Frank, J.S. (1990). Assessment of balance control in humans. Med Prog Technol, 16(1-2), 31-51.

Yıldırım, Y., Yılmaz, S., Ayhan, E., Saygı, S., Yanaral, F., Zubarioğlu, U.A., Kasapçopur, O., Arısoy, N. (2005). The frequency of joint hypermobility in healty school children. Turkish Pediatrics, 40, 83-86. 